\title{
PRODUCTION OF OZONE IN CHAMONIX VALLEY (FRANCE)
}

\section{Eric Chaxel ${ }^{\mathrm{a}}$, Jean-Pierre Chollet, Guillaume Brulfert and Charles Chemel}

Laboratoire des Ecoulements Géophysiques et Industriels, UMR 5519, Université Joseph Fourrier, Institut National Polytechnique de Grenoble et Centre National de la Recherche Scientifique, BP 53, 38041 Grenoble Cedex 9, France.

\begin{abstract}
In the framework of the POVA program a numerical investigation aims to better understand how a reduction of traffic emissions can affect air quality in the Chamonix valley (France). The MM5 model coupled with the Chemistry Transport Model (CTM) TAPOM using a $1 \mathrm{~km}$-cell grid for the period 5-12 July 2003 showed that the ozone formation in the Chamonix valley was strongly NOx-saturated. A comparison with physical and chemical measurements (tethered balloon, UHF radar, monitoring data) prove the temperature profile and the up- and downhill thermally-driven winds to be reasonably well described by MM5. Moreover spatial and temporal variation of $\mathrm{O}_{3}$ concentration is well described by TAPOM. Ozone production within the valley is estimated to 20 to $30 \mu \mathrm{g} / \mathrm{m}^{3}$ and $10 \mu \mathrm{g} / \mathrm{m}^{3}$ are locally produced from precursors emitted by international traffic through the tunnel.
\end{abstract}

Keywords: Air pollution, mesoscale modelling, complex terrain, Alpine valleys, photochemistry, ozone.

\section{Introduction}

During the summer 2003 a POVA Intensive Observation Period (IOP) aimed at determining the sources of airborne pollutants and monitoring their concentrations in two French Alpine valleys: the Chamonix and the Maurienne valleys (see Figure 1 for geographic location). The Pollution of Alpine Valleys (POVA) program was launched in 2000 after the traffic interruption under the Mont-Blanc that followed the tragic accident in the tunnel. The Mont-Blanc tunnel was reopened at the end of 2002 what caused the high duty vehicle traffic (about 1100 trucks per day) to be back in the Chamonix and the Courmayeur (Italy) valleys. The summer 2003 IOP was the last of a series of four IOPs (two in wintertime and two in summertime) and took place from 5 to 12 July in the Chamonix valley. To better understand the very particular atmospheric circulation and to study the chemical reactions of airborne pollutants within the valleys mesoscale modelling is applied. For the calculation of meteorological fields, the fifth generation PSU/NCAR Mesoscale Model (MM5) was used at scales ranging from 27 to $1 \mathrm{~km}$. MM5

\footnotetext{
${ }^{a}$ Correspondence address: Eric Chaxel, Laboratoire des Ecoulements Géophysiques et Industriel, BP 53, 38041 Grenoble cedex 09, France; fax: (+33) 4768270 22; phone: (+33) 4768270 60; e-mail: eric.chaxel@hmg.inpg.fr
} 


\section{Chaxel et al.}

was coupled offline with the Chemistry Transport Model (CTM) CHIMERE at regional scales and with the CTM TAPOM at a $1-\mathrm{km}$ resolution. Simulations were performed for the period 5-12 July 2003 with different emission sets aiming at studying the impact of the international road traffic of the valley on airborne pollutant concentration. This traffic includes the traffic on the main highway leading to the valley, on the ramp to access the tunnel and through the tunnel. A high ozone event occurred from 5 to 14 July at regional scale and caused the ozone background concentration to increase. In order to correctly describe the background concentrations the use of nested models was compulsory.
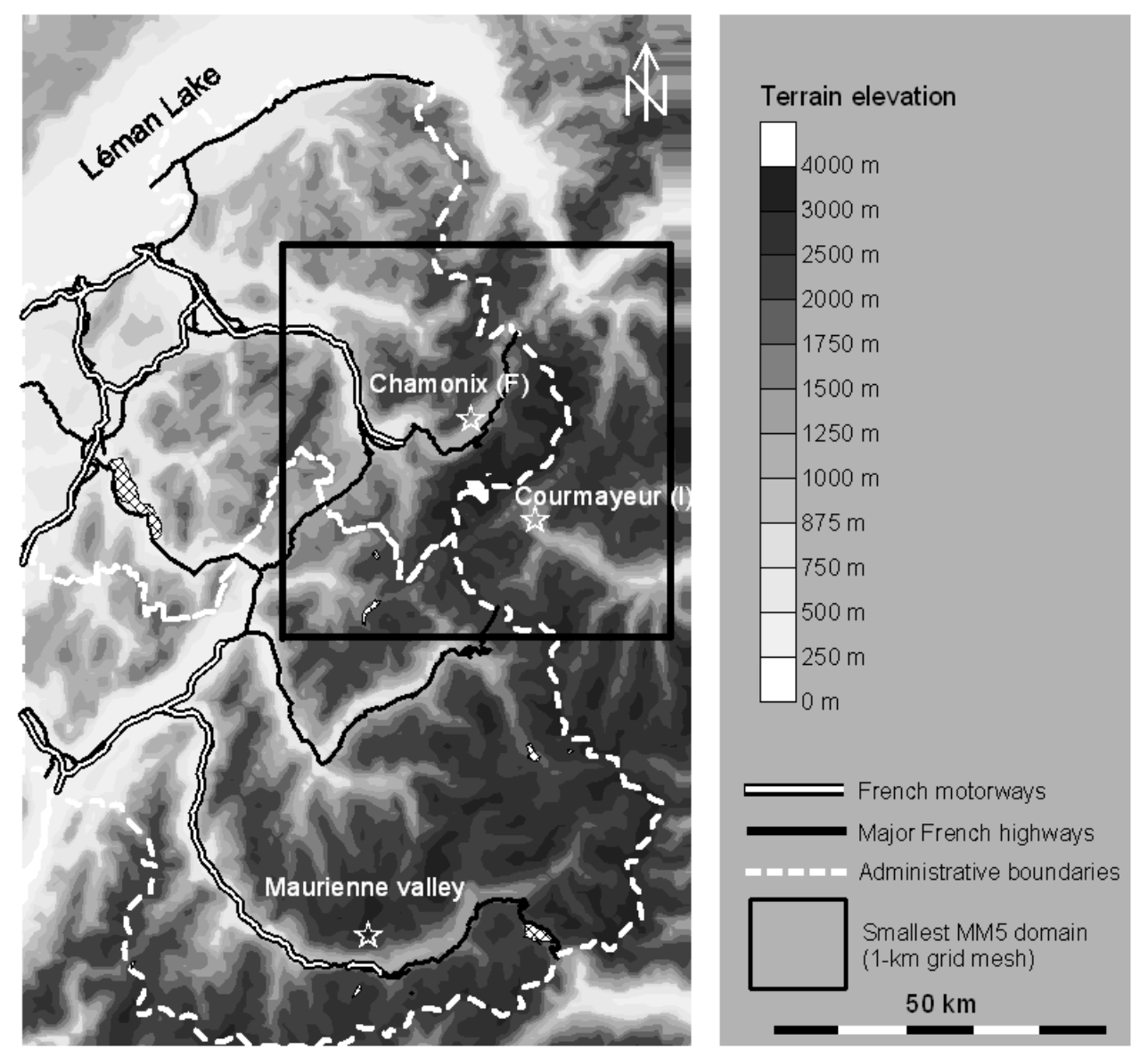

Figure 1. Geographic location of major roads in the study area

\section{Methodology}

Before describing atmospheric processes within the valley such as slope winds, thermal inversions and ozone production, a good description of the meteorological synoptic situation must be performed with regional models. MM5 was chosen to be used at the 


\section{Production of Ozone in Chamonix valley}

different scales and gave good results both at the synoptic and at the local scale when compared with available measurements of wind, temperature and humidity. The two CTMs CHIMERE (Vautard et al., 2003) and TAPOM (Clappier, 1998; Gong et Cho, 1993) are then powered with MM5 meteorological fields. The temporal variations of concentrations at the continental and regional scales for main airborne pollutants are resolved with the CHIMERE model in its recent multi-scale nested version. TAPOM calculates concentration at finer resolution with $1 \times 1 \mathrm{~km}$ grid cells. The interaction between the different models and domains is presented in Figure 2. Additional calculations which are not reported here and performed in the framework of the POVA program are performed at a 300-meter scale with the Advanced Regional Prediction System (ARPS) code and TAPOM (Chemel et al., 2004; Brulfert et al., 2004).

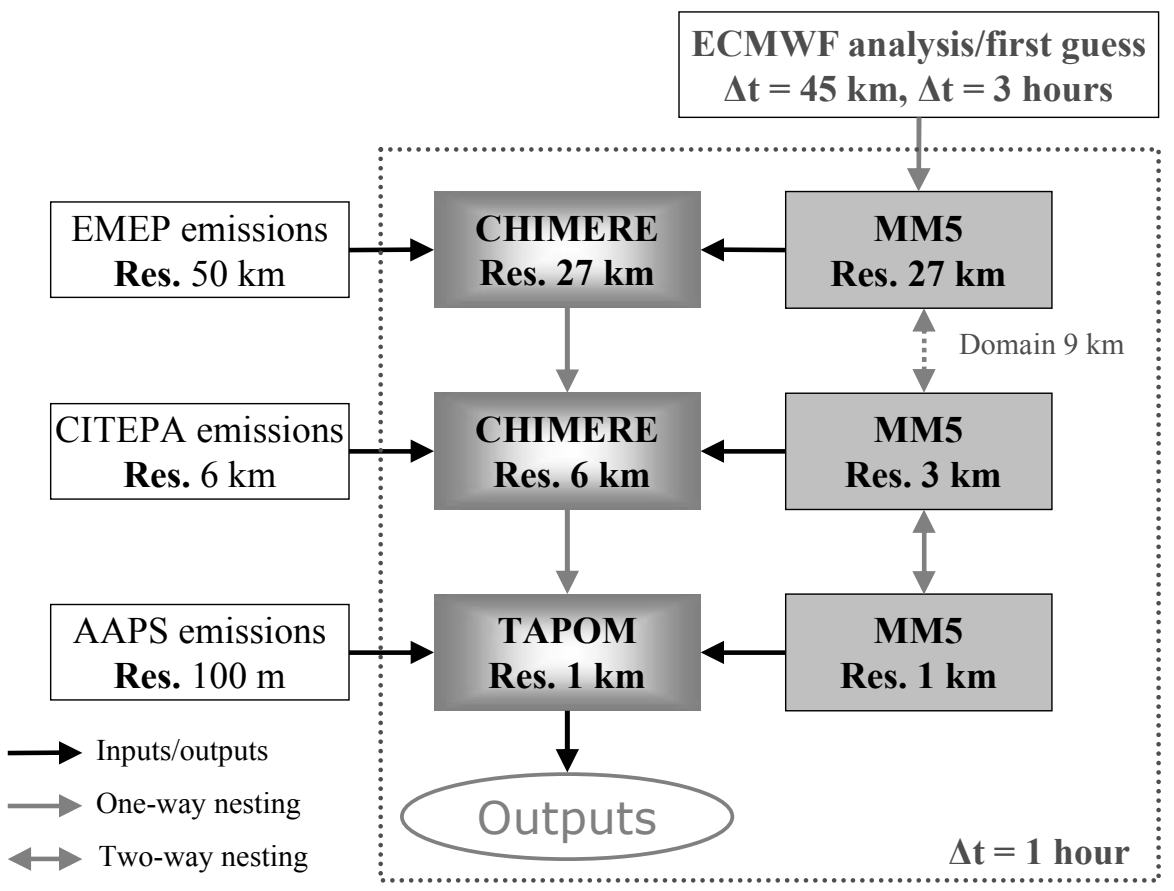

Figure 2. Schematic of the simulation system and its main inputs

\subsection{Meteorological Calculation}

The fifth-generation PSU/NCAR mesoscale model (MM5) is a nonhydrostatic code which allows meteorological calculations at various scales with a two-way nesting technique described by Grell et al. (1994). For our simulations three different domains with intermediate resolutions have to be considered at $27 \mathrm{~km}, 9 \mathrm{~km}$ and $3 \mathrm{~km}$, respectively, in order to appropriately force boundary condition of the 1-km grid mesh domain as shown in Figure 2. The typical extents and resolutions of the four domains are also given in Table 1. The smallest domain has a 1-km grid mesh and is geographically located in Figure 1. The coarsest domain is powered with the European Centre for 


\section{Chaxel et al.}

Medium-Range Weather Forecasts (ECMWF) gridded analysis and first guess available at a $0.5^{\circ}$ resolution. The Four Dimensional Data Analysis (FDDA) technique available in MM5 is used in the coarse domain to provide a better synoptic forcing of the smallest ones. Vertically MM5 uses 27 half sigma-pressure levels with thickness ranging from 35 $\mathrm{m}$ at the ground to $2000 \mathrm{~m}$ at $15000 \mathrm{~m}$. The top of the model is at the pressure $100 \mathrm{hPa}$. In this configuration the planetary boundary layer (PBL) is described with about 15 layers from 0 to $2000 \mathrm{~m}$ agl. PBL height calculation is performed by the MRF scheme described by Hong and Pan (1996). For our calculations PBL height calculated from MM5 is used by TAPOM to compute turbulent diffusion coefficient $K_{z}$ in the mixing layer.

Table 1. Domains used for meteorological calculation

\begin{tabular}{ccccc}
\hline Domain & Mesh size $(\mathrm{km})$ & $\mathrm{nx}$ & ny & Geographical area and typical extent \\
\hline 1 & 27 & 45 & 51 & France $(1500 \mathrm{~km})$ \\
2 & 9 & 69 & 63 & Southeasterly France $(650 \mathrm{~km})$ \\
3 & 3 & 96 & 96 & Savoie mountains $(300 \mathrm{~km})$ \\
4 & 1 & 57 & 57 & Chamonix valley $(55 \mathrm{~km})$ \\
\hline
\end{tabular}

\subsection{Chemistry Transport Calculation}

As shown in Figure 2, CHIMERE code is used in two configurations: on a domain with a 27-km grid mesh covering Central Europe (called continental) and on a domain with a 6$\mathrm{km}$ grid mesh covering Rhône-Alpes region (called regional). The grid mesh of the continental domain of CHIMERE has been defined by using the grid mesh of MM5 at $27-\mathrm{km}$ resolution. The grid mesh of the CHIMERE regional domain is based on the mesh of the emission inventory at the $6-\mathrm{km}$ resolution and the extent of the corresponding domain is $240 \mathrm{~km}$ by $240 \mathrm{~km}$. The chemical mechanism MELCHIOR implemented in the CHIMERE code calculates concentrations of 44 species following a set of 116 reactions. MELCHIOR was developed by Derognat (1998) based on EMEP mechanism. CHIMERE is powered off-line with MM5 meteorological fields (see the model technical documentation for details) and resolves transport with the PPM (Piecewise Parabolic Method) $3^{\text {rd }}$ order scheme described by Colella and Woodward (1984). The cloud effects and dry deposition are taken into account in ozone production and destruction. CHIMERE has 8 hybrid sigma-p levels with the model top at $500 \mathrm{hPa}$ (equivalent to $5600 \mathrm{~m}$ amsl). To account for stratospheric ozone climatological values from the version 2 of the MOZART model (Horowitz et al., 2003) are used at its top. The continental domain is initialised with MOZART values and runs from 2 to 14 July 2003. At the boundaries concentrations from MOZART are also used. The calculation on the regional domain runs from 3 to 14 July 2003 and is initialised with results obtained from the continental domain. Results for 20 MELCHIOR species from the regional domain are then used at the boundaries and at the top of the TAPOM model. TAPOM runs from 5 to 12 July 2003, what represents a 3-day spin up compared with CHIMERE simulations.

TAPOM also uses the PPM scheme for transport and a semi-implicit scheme for diffusion with $1 \times 1 \mathrm{~km}$ grid cells horizontally and on 12 terrain-following levels vertically. The Regional Atmospheric Chemistry Mechanism (RACM) (Stockwell et al., 1997) implemented in TAPOM resolves chemistry with 77 species and a set of 237 


\section{Production of Ozone in Chamonix valley}

reactions. The model top is set at $8000 \mathrm{~m}$ amsl. RACM and MELCHIOR mechanisms have different chemical species and reactions. The passage from RACM to TAPOM is performed according to Table 2.

Table 2. RACM species related to MELCHIOR species for using CHIMERE concentrations at TAPOM boundaries

\begin{tabular}{|c|c|c|c|}
\hline $\begin{array}{l}\text { MELCHIOR } \\
\text { species }\end{array}$ & $\begin{array}{l}\text { MELCHIOR } \\
\text { description }\end{array}$ & $\begin{array}{l}\text { RACM } \\
\text { species }\end{array}$ & RACM description \\
\hline $\mathrm{O} 3$ & ozone & $\mathrm{O} 3$ & ozone \\
\hline $\mathrm{NO} 2$ & nitrogen dioxide & $\mathrm{NO} 2$ & nitrogen dioxide \\
\hline NO & nitric oxide & NO & nitric oxide \\
\hline PAN & $\begin{array}{l}\text { peroxyacetyl } \\
\text { nitrate }\end{array}$ & PAN & peroxyacetyl nitrate and higher saturated PANs \\
\hline HNO3 & nitric acid & HNO3 & nitric acid \\
\hline $\mathrm{SO} 2$ & sulphur dioxide & $\mathrm{SO} 2$ & sulphur dioxide \\
\hline $\mathrm{CO}$ & carbon monoxide & $\mathrm{CO}$ & carbon monoxide \\
\hline $\mathrm{CH} 4$ & methane & $\mathrm{CH} 4$ & methane \\
\hline $\mathrm{C} 2 \mathrm{H} 6$ & ethane & ETH & ethane \\
\hline $\mathrm{NC} 4 \mathrm{H} 10$ & n-butane & HC5 & $\begin{array}{l}\text { alkanes, alcohols, esters and alkynes with } \mathrm{HO} \text { rate } \\
\text { between } 3.4^{*} 10^{-12} \text { and } 6.8^{*} 10^{-12} \mathrm{~cm}^{3} \mathrm{~s}^{-1}\end{array}$ \\
\hline $\mathrm{C} 2 \mathrm{H} 4$ & ethene & ETE & ethene \\
\hline $\mathrm{C} 3 \mathrm{H} 6$ & propene & OLT & terminal alkenes \\
\hline OXYL & o-xylene & TOL & toluene and less reactive aromatics \\
\hline C5H8 & isoprene & ISO & isoprene \\
\hline APINEN & $\alpha$-pinene & API & $\begin{array}{l}\alpha \text {-pinene and other cyclic terpenes with one double } \\
\text { bond }\end{array}$ \\
\hline $\mathrm{HCHO}$ & formaldehyde & $\mathrm{HCHO}$ & formaldehyde \\
\hline $\mathrm{CH} 3 \mathrm{CHO}$ & acetaldehyde & ALD & acetaldehyde and higher aldehydes \\
\hline GLYOX & glyoxal & GLY & glyoxal \\
\hline MGLYOX & methyl glyoxal & MGLY & methylglyoxal and other $\alpha$-carbonyl aldehydes \\
\hline $\mathrm{CH} 3 \mathrm{COE}$ & $\begin{array}{l}\text { methyl ethyl } \\
\text { ketone }\end{array}$ & KET & ketones \\
\hline
\end{tabular}

Chemical concentrations calculated on the regional domain of CHIMERE are vertically interpolated at TAPOM levels. Above the top of CHIMERE domain (from 5600 to 8000 $\mathrm{m}$ amsl), values of the top level of CHIMERE are used at the top and at high altitude lateral boundaries of TAPOM. The use of nested domains at continental and regional scales provides a good description of the temporal variation of the background concentration of ozone and other secondary species. Over this one-week simulation period CHIMERE correctly deals with the important smog episode that occurred at continental scale during the period 5-12 July 2003. 


\section{Chaxel et al.}

\subsection{Anthropogenic Emission Inventories}

Each emission inventory used for simulations has a precision consistent with the associated CTM model. As shown in Figure 2, the EMEP emission inventory of 2001 for NOx, SOx, CO and NMVOC on a 50-km grid mesh is used in the continental domain (at a $27-\mathrm{km}$ resolution) of CHIMERE model by recalculating emissions following land use. The EMEP emission inventory is described by EEA (2003) and includes anthropogenic emissions for 10 classes of sources referred as SNAP. To perform chemistry-transport calculation at 6-km resolution in the regional domain of CHIMERE for the Rhône-Alpes region a 6-km resolution emission inventory from CITEPA (Bouscaren et al., 1999; Couach et al., 2004) including 7 classes (following the SNAP classification) of sources is used for NOx, CO, NMVOC and SOx. At the smallest scale an accurate emission inventory based on the CORINAIR methodology and developed in the framework of the POVA program by the local agency Air de l'Ain et des Pays de Savoie with a 100-m resolution is distributed on the 1-km grid mesh used for the TAPOM calculation. Hourly emissions for CHIMERE are computed from the total annual EMEP and CITEPA emissions by assigning hourly coefficients depending on the SNAP class, the month and the day of the week. Hourly emissions for TAPOM are computed from annual emissions by assigning hourly coefficients depending on the source type, the month and the day of the week. The NMVOC emissions are split into 9 classes represented within the MELCHIOR mechanism and into 32 classes represented within the RACM mechanism. In simulation the tunnel is represented by one point source, the tunnel entrance, on the French side and accounts for one half of the total emissions in the tunnel.

\subsection{Biogenic Emissions}

Hourly biogenic emissions of isoprene and terpenes (allocated to alpha-pinene in the MELCHIOR chemical mechanism) at continental and regional scales are calculated by the CHIMERE model following the tree species distribution, the temperature and the solar radiation. Hourly biogenic emissions in TAPOM are already included in the inventory as forested areas or grassland and are aggregated into the RACM classes ISO and API (see Table 2 for description).

\subsection{Definition of the Emission Scenarios}

Beside the base case two scenarios for emissions are considered. The base case (BC) takes into account all the emissions for 2003. Emissions for the first scenario (S1) are computed based on 1-km emissions by assigning multiplicative factors to each type of sources given in Table 3. S1 aims at determining which part of ozone is produced by the vehicles using the Mont-Blanc tunnel between France and Italy. This international traffic is mainly distributed along the RN 205 road in Figure 3. The second scenario (S2) aims at determining which part of ozone is produced by all the sources in the valley, biogenic and anthropogenic, and then all emissions are shut off. For the first scenario road counting realized by local agencies and by the company operating the Mont-Blanc tunnel showed that traffic could be modelled as shown in Table 3 . 
Production of Ozone in Chamonix valley

Table 3. Definition of the multiplicative factors assigned to 2003 hourly emissions for different source classes for the base case (BC) and the two scenarios S1 and S2.

\begin{tabular}{lccc}
\hline Source classes & $\begin{array}{c}\text { BC: With } \\
\text { the tunnel }\end{array}$ & $\begin{array}{c}\text { S1: Without } \\
\text { the tunnel }\end{array}$ & $\begin{array}{c}\text { S2: Without } \\
\text { emission }\end{array}$ \\
\hline Biogenic emissions & 1 & 1 & 0 \\
Personal light duty vehicles on roads & 1 & 0.9 & 0 \\
Personal light duty vehicles in city & 1 & 1 & 0 \\
Commercial light duty vehicles on roads & 1 & 0.5 & 0 \\
Commercial light duty vehicles in city & 1 & 0.9 & 0 \\
Heavy duty vehicles & 1 & 0.04 & 0 \\
\hline
\end{tabular}

\section{Results}

\subsection{Description of the Base Case}

The validation of the meteorological fields computed by MM5 was realised using ground station data, a tethered balloon, an instrumented cable car and an UHF radar windprofiler located in the Chamonix valley. The geographic location of the different stations and devices is given in Figure 3.

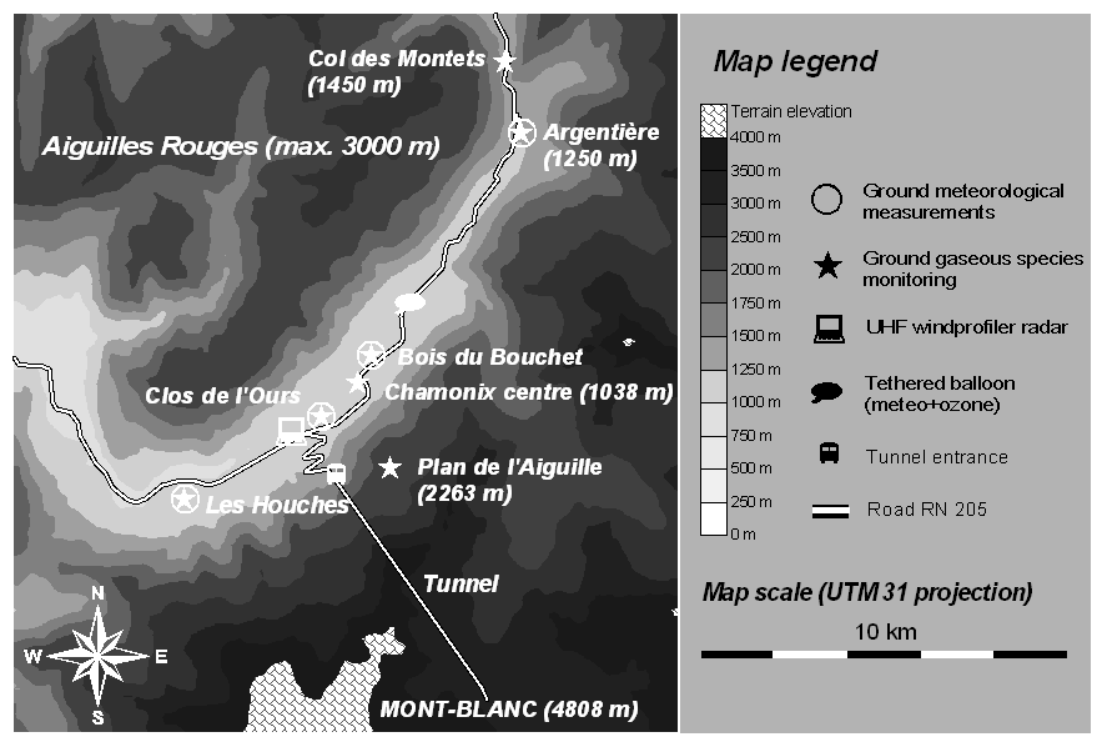

Figure 3. Ground station locations, UHF radar and tethered balloon location in the Chamonix valley with respective available measurements (chemical and meteorological). 


\section{Chaxel et al.}

MM5 correctly describes the wind reversal between directions $30^{\circ}$ and $210^{\circ}$ that occurs twice a day at 0600 UTC and 2000 UTC as shown in Figure 4a. During the day the heating of the slopes by solar radiation enables the development of up-slope winds. Their speed reaches $2 \mathrm{~m} / \mathrm{s}$ at $100 \mathrm{~m}$ agl at noon on south-oriented slopes. During the night cooling of the ground by IR radiation generates very weak down-slope winds with mean speed often below $0.5 \mathrm{~m} / \mathrm{s}$ depending on slope. The thickness of this flow is poorly resolved by MM5 but an estimation of $75 \mathrm{~m}$ agl can be proposed for slopes above Chamonix. Slope wind is captured in the two first layers which correspond to approximately $75 \mathrm{~m}$ above ground level but due to the terrain following coordinate, this height is not constant over the entire domain.

The impact of cooling by glaciers above Chamonix has been well resolved in simulations; for example cool down-slope winds with speed of $1.5 \mathrm{~m} / \mathrm{s}$ are simulated over the Bossons glacier at night. As shown in Figure $4 \mathrm{a}$ the southwesterly wind resulting from slope winds and blowing along the valley axis from 0600 UTC to 2000 UTC has a vertical extent of $1300 \mathrm{~m}$ agl. During the night the northeasterly valley wind blows from 2000 UTC to 0600 UTC and has a vertical mean extent of $500 \mathrm{~m}$ agl at the vertical of Chamonix. The wind speeds characterising the two wind regimes are well reproduced by MM5 as shown in Figure 4b. During the day strong winds up to $6 \mathrm{~m} / \mathrm{s}$ in the first $1200 \mathrm{~m}$ above the ground according to the measurements are slightly underestimated by MM5, considering that the windprofiler has a uncertainty of $1 \mathrm{~m} / \mathrm{s}$. The temporal variations are linked with the wind direction and are well reproduced. MM5 is also able to correctly detect the limit between the local wind system and synoptic wind. This limit can be characterised by a wind shear in Figure $4 \mathrm{a}$ and by very weak winds in Figure $4 \mathrm{~b}$ and is detected around $1600 \mathrm{~m}$ agl at night and around $2400 \mathrm{~m}$ agl during the day.

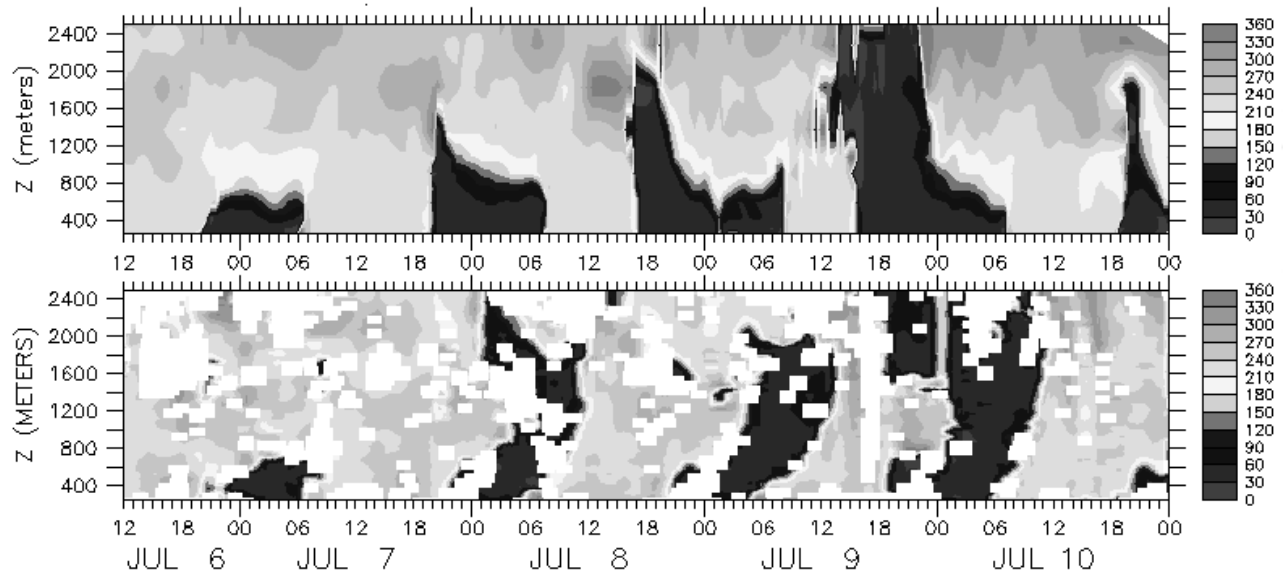

Figure 4a. Wind direction (in degrees clockwise from north) modelled by MM5 (up) and measured with UHF radar (down) from 250 to $2500 \mathrm{~m}$ above the ground at the vertical of Chamonix from 6 to $10 \mathrm{July}$. A wind reversal between directions $30^{\circ}$ and $210^{\circ}$ occurs every day at 0600 UTC and 2000 UTC. 


\section{Production of Ozone in Chamonix valley}
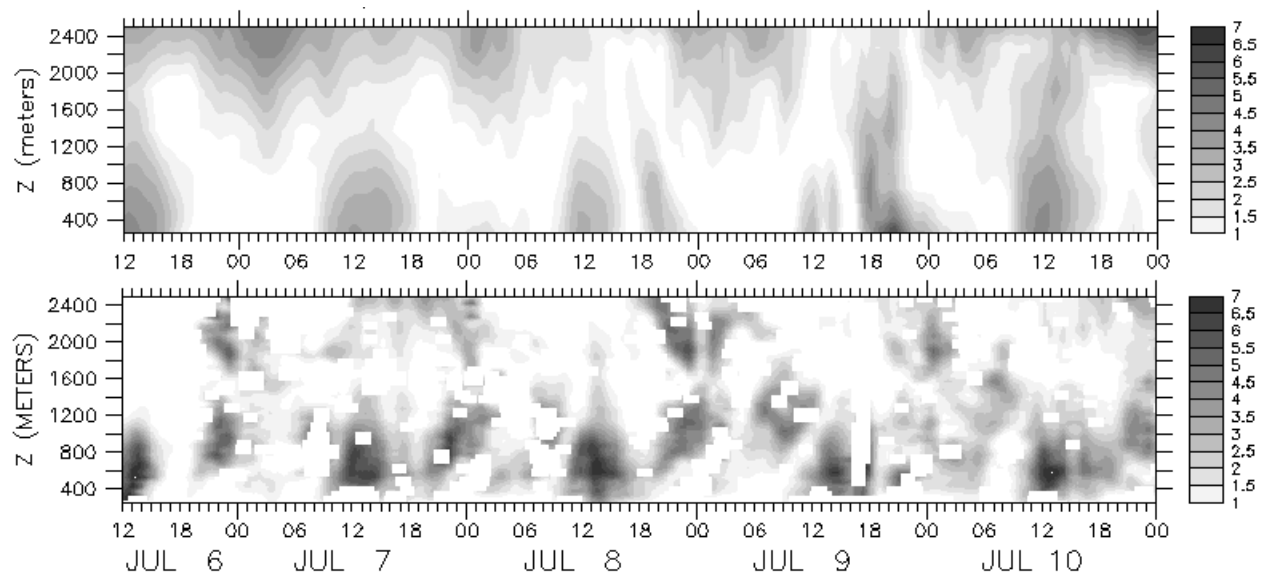

Figure 4b. Wind speed (in $\mathrm{m} \mathrm{s}^{-1}$ ) modelled by MM5 (up) and measured with UHF radar (down) from 250 to $2500 \mathrm{~m}$ above the ground at the vertical of Chamonix from 6 to 10 July.

The PBL height in Figure 5 is experimentally determined with ozone profiles of the tethered balloon from 0 to $300 \mathrm{~m}$ agl and with wind profiles of the windprofiler from 400 to $2500 \mathrm{~m}$ agl. Both devices were operated during POVA IOP 4 in Chamonix from 5 to 12 July 2003 and are located in Figure 3. Figure 5 shows that on 8 July morning MM5 calculates PBL heights that are twice greater than heights determined from the available measurements. But even if the PBL rise simulated by MM5 is too fast during the morning the maximum PBL height of $1300 \mathrm{~m}$ agl that is reached at 1400 UTC is well reproduced. The disagreement between MM5 and the measurements during the morning transition is likely due to the shadowing effect of the Mont-Blanc in the valley that prevents the sun rays to heat the ground in the morning what causes the PBL rise to be slower than with the full direct radiation. MM5 does not account for this shadowing effect what may cause the PBL to rise faster. This bad description of the rise of the PBL may cause the simulated coefficients of vertical turbulent dispersion to be overestimated during the morning.

The validation of chemical-transport calculation was realised using the ground station network of Figure 3. The validation for the base case in Figure 6 shows very good agreement of the modelled concentrations of ozone with hourly measurements at rural and ranged sites. Two comparisons are shown in Figure 7 and Figure 8 respectively for the suburban site Clos de l'Ours (1038 m amsl) and for the high-altitude site col des Montets (1450 m amsl). For other pollutants such as nitrogen dioxide, temporal variations are less satisfactorily described at source-influenced sites but still in agreement with measurements at background sites located in the Chamonix urban area and at ranged sites. 
Chaxel et al.

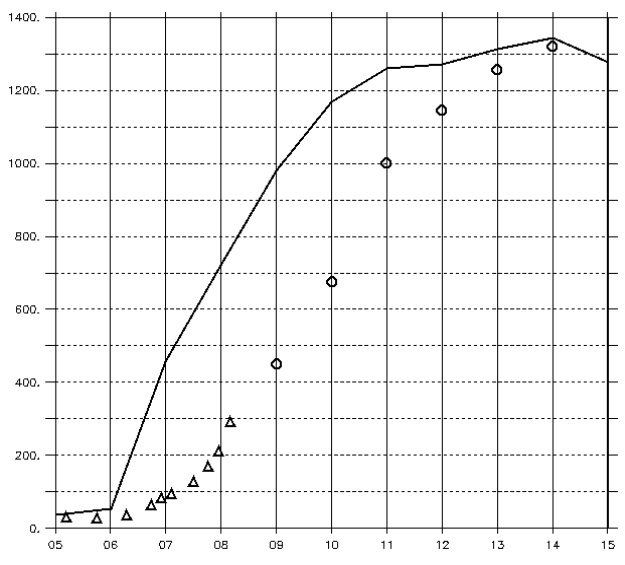

Figure 5. Determination of PBL height (in meters agl) growth during the morning with MM5 (line), tethered balloon (triangles) and windprofiler (dots) on 8 July. Timescale is UTC.

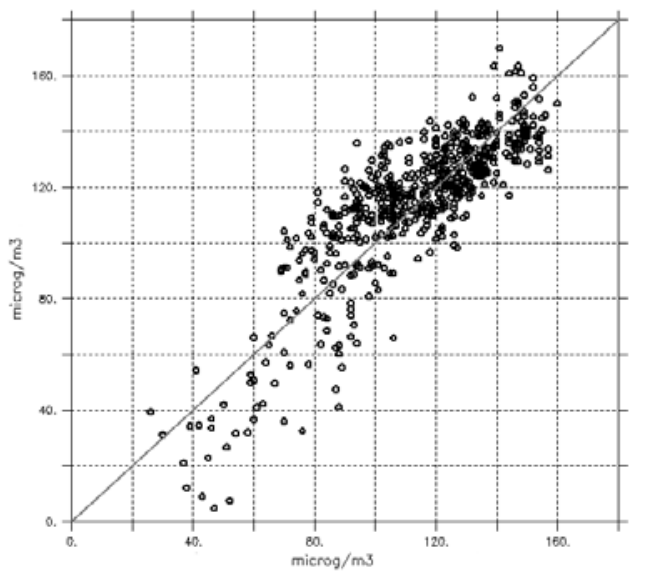

Figure 6. Observed versus modelled hourly concentrations of ozone (in $\mu \mathrm{g} / \mathrm{m}^{3}$ ) at two rural sites (les Houches, Argentière) and two high-altitude sites (plan de l'Aiguille, col des Montets).

Both TAPOM results and measurements show different temporal evolutions of ozone concentrations depending on the part of the domain and the typology of monitoring sites. The ranged site col des Montets (in Figure 8) catches very well the increase of ozone concentrations in the free troposphere from 5 to 9 July. After 9 July the ozone concentration does not exceed $140 \mu \mathrm{g} / \mathrm{m}^{3}$. At sites located at the bottom of the valley, as Clos de l'Ours in Figure 7, diurnal variations of ozone concentrations are well modelled with low values at night characterising source-influenced sites.

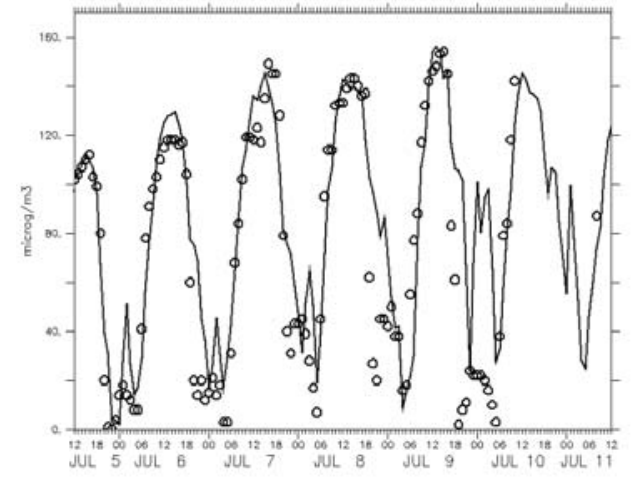

Figure 7. Measured (dots) and modelled (line) hourly concentrations of ozone at the suburban monitoring site Clos de l'Ours from 8 to 12 July 2003.

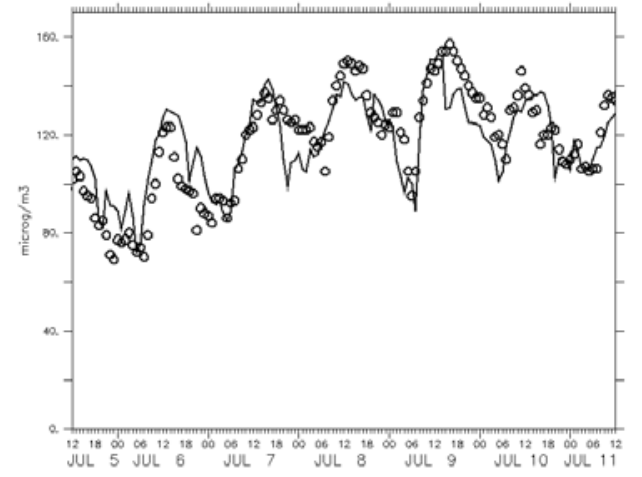

Figure 8. Measured (dots) and modelled (line) hourly concentrations of ozone at the ranged monitoring site col des Montets from 8 to 12 July 2003.

The processes leading to the observed concentrations are very different at night and during daytime. During the day the strong valley wind system with slope winds generated 


\section{Production of Ozone in Chamonix valley}

by convection and the main valley wind blowing in the central part of the valley is performing a very effective dispersion and a fast transport of ozone precursors from the sources to higher altitude areas. The combination of the main valley wind and slope winds causes the formation of two ozone plumes downwind of the Chamonix urban area. The production of ozone in these plumes is enhanced by the availability on the slopes of the valley of large amount of biogenic VOC such as terpenes. The simulated production rate of ozone in the central part of the valley is $2 \mu \mathrm{g} / \mathrm{m}^{3} / \mathrm{h}$ whereas it reaches $5 \mu \mathrm{g} / \mathrm{m}^{3} / \mathrm{h}$ on the south face of Aiguilles Rouges Mountains. This transport starts when the valley wind sets up at 0600 UTC and is really effective from 0800 UTC to noon. The calculated ozone concentration in the plumes reaches $170 \mu \mathrm{g} / \mathrm{m}^{3}$ on 9 July whereas the background concentration is $150 \mu \mathrm{g} / \mathrm{m}^{3}$ what represents a net production of $20 \mu \mathrm{g} / \mathrm{m}^{3}$ in the valley. The base case simulation highlights that the maximums of ozone are linked with the background ozone level because of intensive mixing that brings air from free troposphere. At sunset the convection stops and the valley wind weakens progressively down to zero at 1800 UTC. The atmosphere becomes stable and primary pollutants such as NOx are accumulated in the surface layer. Titration of ozone by NO and dry deposition cause ozone concentration to rapidly decrease at urban and suburban sites. In Figure 7 ozone concentration reaches $0 \mu \mathrm{g} / \mathrm{m}^{3}$ at $1900 \mathrm{UTC}$ on 9 July at the site Clos de l'Ours. The three other monitoring sites Chamonix centre, les Houches and Bois du Bouchet located at the bottom of the valley have the same behaviour. At ranged sites col des Montets and plan de l'Aiguille ozone concentration is mainly under the control of long distance transport and dry deposition and so smaller temporal variation is simulated and observed (Figure 8).

\subsection{Impact of International Traffic on Ozone Production (S1)}

The simulation performed without the emissions of the tunnel gives very similar results as the base case during the day because of the strong dependency of ozone concentrations in the valley with the regional background. However the simulation shows that the two ozone plumes downwind of Chamonix have lower concentrations. The plumes are well visible on 8 July at 1200 UTC in Figure 9. Depending on the day the difference between the base case and the case without tunnel emissions is in the range $2-7 \mu \mathrm{g} / \mathrm{m}^{3}$ as shown in Figure 10. Figure 10 also shows that international traffic has a stronger impact on ozone maximums for week days ( 7 to 11 July) than during the week end (5 and 6 July). The net production in the plumes remains negligible in regard with the amount of ozone that is produced regionally and that is advected above the valley and mixed in. Shutting off traffic emissions has a sensible effect at night when the reduction of emitted NOx causes ozone concentration to be higher than in the base case. The titration of ozone is obviously less effective with lower NOx concentrations. Ozone destruction is observed during the day at some sites what means that at these sites ozone production is strongly VOClimited (or NOx-saturated). This ozone destruction regime by NOx is observed at sourceinfluenced sites such as the traffic site Bossons or Chamonix centre. 
Chaxel et al.

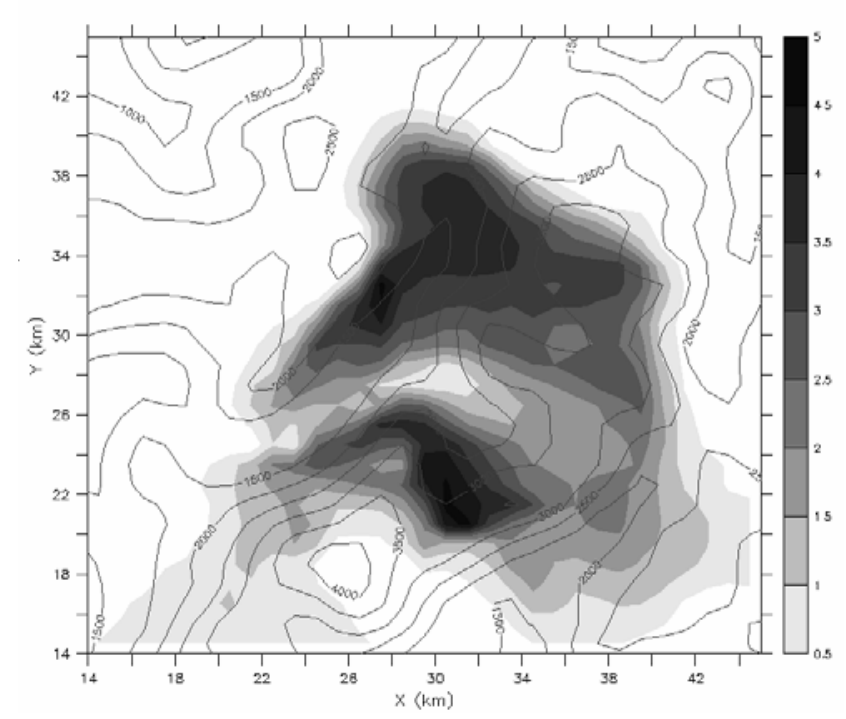

Figure 9. Contour plot of topography with mapped ozone concentration reductions (in $\mu \mathrm{g} / \mathrm{m}^{3}$ ) without emissions of international traffic in the valley (S1) on 8 July 2003 at 1200 UTC.

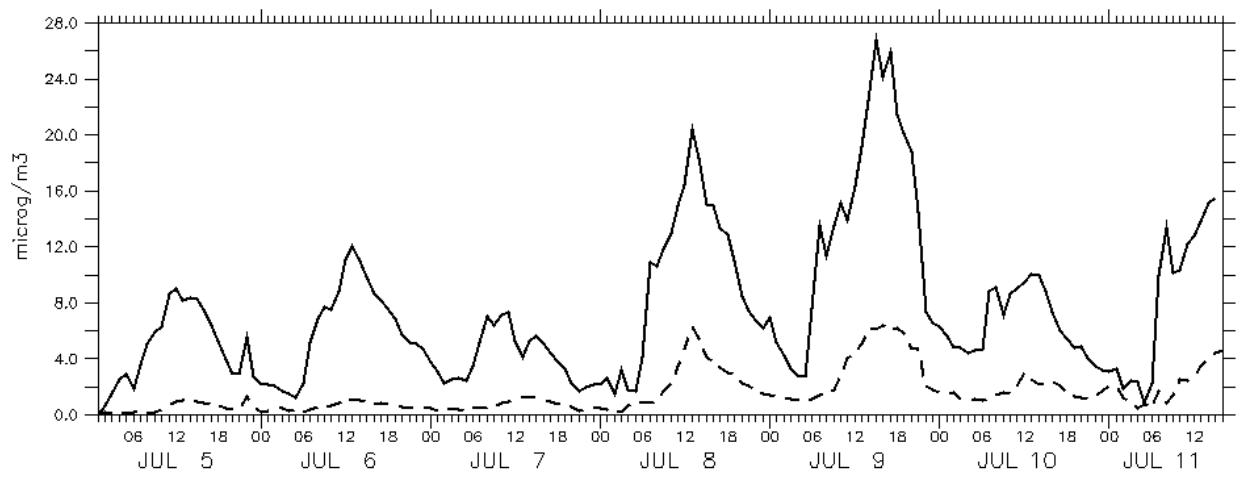

Figure 10. Difference between the maximums of ozone concentration in the base case and the scenario 1 (dashed line) and in the base case and the scenario 2 (solid line). Positive values indicate that the maximum values of the base case are always greater than values calculated for scenarios 1 and 2 .

\subsection{Impact of all Local Sources on Ozone Production (S2)}

In order to determine the total production of ozone in the valley a simple way to proceed is to set all the emissions of the valley to zero. In this case the processes that efficiently control variation in ozone concentration are: long distance transport by advection, mixing, UV radiation and dry deposition. Depending on the day the difference between ozone maximums in the base case and in the scenario $\mathrm{S} 2$ is in the range $8-27 \mu \mathrm{g} / \mathrm{m}^{3}$ as 


\section{Production of Ozone in Chamonix valley}

shown in Figure 10 what is roughly 5 to $15 \%$ of ozone maximum. Figure 10 also shows that the local production in the domain was the strongest on 9 July. This day was characterised by very weak winds that enhanced ozone production.

Table 4. Maximum reduction of hourly ozone concentrations (in $\mu \mathrm{g} / \mathrm{m}^{3}$ ) at monitoring sites by applying S2 for each day of the IOP. (+) indicates augmentation, (-) indicates diminution. Monitoring sites are located on the Figure 3.

\begin{tabular}{llllllllll}
\hline \multirow{2}{*}{ Site } & Typology & $\begin{array}{l}\text { Downwind } \\
\text { of } \\
\text { Chamonix }\end{array}$ & $\begin{array}{l}\text { Sat. } \\
05 / 07\end{array}$ & $\begin{array}{l}\text { Sun. } \\
06 / 07\end{array}$ & $\begin{array}{l}\text { Mon. } \\
07 / 07\end{array}$ & $\begin{array}{l}\text { Tues. } \\
08 / 07\end{array}$ & $\begin{array}{l}\text { Wed. } \\
09 / 07\end{array}$ & $\begin{array}{l}\text { Thu. } \\
10 / 07\end{array}$ & $\begin{array}{l}\text { Fri. } \\
11 / 07\end{array}$ \\
\hline Houches & Rural & no & $-5(+)$ & $-5(+)$ & $-3(+)$ & $1(-)$ & $-6(+)$ & $-4(+)$ & $-2(+)$ \\
Bossons & Traffic & no & $-2(+)$ & $-3(+)$ & $-1(+)$ & $4(-)$ & $-8(+)$ & $-3(+)$ & $-2(+)$ \\
Clos de l'O. & Suburban & no & $-2(+)$ & $-3(+)$ & $-1(+)$ & $4(-)$ & $-8(+)$ & $-2(+)$ & $-1(+)$ \\
Chamonix & Centre & no & $-2(+)$ & $-3(+)$ & $-1(+)$ & $6(-)$ & $-3(+)$ & $-2(+)$ & $2(-)$ \\
Plan de l'A. & Ranged & yes & $4(-)$ & $3(-)$ & $2(-)$ & $10(-)$ & $10(-)$ & $3(-)$ & $8(-)$ \\
Bouchet & Suburban & yes & $0(-)$ & $-2(+)$ & 0 & $7(-)$ & $5(-)$ & $1(-)$ & $3(-)$ \\
Argentière & Rural & yes & $4(-)$ & $3(-)$ & $2(-)$ & $12(-)$ & $18(-)$ & $6(-)$ & $12(-)$ \\
Montets & Ranged & yes & $6(-)$ & $5(-)$ & $3(-)$ & $14(-)$ & $14(-)$ & $9(-)$ & $10(-)$ \\
\hline
\end{tabular}

Although ozone production in the model domain is clearly detected by the simulation (Figure 10) some monitoring sites do not experience a reduction in ozone with scenario S2. Recent studies (Brulfert et al., 2003) with photochemical indicators showed that the ozone production regime was strongly NOx-saturated (VOC-limited) inside the valley and becomes NOx-limited (VOC-saturated) at high-altitude sites. Table 4 shows that only sites located downwind of Chamonix experience ozone reduction except on 8 July when all sites experience reduction. This result shows that the ozone production in the Chamonix valley only affects the region downwind of Chamonix except days when large amount of photochemical secondary species regionally transported from outside to the valley makes the ozone production regime to become NOx-limited.

\section{Conclusion}

This numerical study based on a chain of nested model highlighted the processes of production and destruction of tropospheric ozone in the very narrow valley of Chamonix (France) for the period 5-12 July 2003. Two pure academic cases of emission reduction in the valley showed that ozone concentrations were regionally controlled during the day whereas during the night under stable conditions the valley was totally decoupled from synoptic conditions. The precursors emitted by the Chamonix urban area and by the traffic are rapidly dispersed during the day forming two plumes downwind of Chamonix at higher altitudes. The net ozone production in the valley during the day accounts for 5 to $15 \%$ of the maximum concentrations of ozone which are in the range $110-170 \mu \mathrm{g} / \mathrm{m}^{3}$ depending on the day. The impact of the tunnel accounts for about $5 \%$ of these concentrations. A dependency of ozone production regime with regional background of photochemical secondary species has been observed with simulations on 8 July but remains to be confirmed by a regional three-dimensional field measurement campaign investigating the area surrounding the valley. The aim of this study was also to evaluate 


\section{Chaxel et al.}

the ability of MM5, which is a regional model dedicated to prediction, to provide meteorological fields for a CTM with a 1-km grid mesh. Even if MM5 gives good results for ozone at this scale it remains too coarse to resolve fine scale processes that control concentrations of primary pollutants such as nitrogen oxides and particulate matter $\left(\mathrm{PM}_{2.5}\right.$ and $\left.\mathrm{PM}_{10}\right)$. It is then interesting to use a finest scale model to better study these species. Additional simulations with MM5 at a 500-m scale showed that the model was unable to work at such scales because processes such as slope winds were resolved twice, explicitly and by the PBL scheme, what causes unrealistic instability to occur near the ground. The use of the MM5 model in modelling applications in very complex terrain should be limited at a 1-km scale until further improvements. The other weakness of MM5 for using it in very complex terrain is the absence of a radiation module dealing with the effect of shading. The dynamical and chemical results of the smallest domain have also been used to provide realistic boundary conditions for finer scale models applied in the framework of the POVA program (Chemel et al., 2004; Brulfert et al., 2004).

\section{Acknoledgements}

The POVA program is supported by Région Rhône Alpes, ADEME, METL, MEDD. Meteorological data are provided by ECMWF, emission inventories by EMEP, CITEPA and Air de l'Ain et des Pays de Savoie, traffic data by STFTR, ATMB, DDE Savoie et Haute Savoie. Calculations were performed on MIRAGE, CINES and IDRIS.

\section{References}

Bouscaren, R., Riviere, E. and Heymann, Y., 1999, Réalisation d'un inventaire d'émissions simplifiées pour la ville de Grenoble ( 1 heure - $1 \mathrm{~km} 2)$, in Convention $\mathrm{n}^{\circ} 98338001$, CITEPA 392.

Brulfert, G., Chaxel, E., Chemel, C. and Chollet, J.P., 2004, Modelling photochemistry in Alpine valley. Submitted to Atmospheric Chemistry and Physics.

Chemel, C., Chollet, J.P., Brulfert, G., and Chaxel, E., 2004, Evolution of convective boundary layer in deep valley for air quality modeling. 11th Conference on Mountain Meteorology and the Annual Mesoscale Alpine Program (MAP). 21-25/06/2004. Mount Washington Valley, $\mathrm{NH}$.

Clappier, A., 1998, A correction method for use in multidimensional time splitting advection algorithms: application to two and three dimensional transport, Mon. Wea. Rev. 126: 232242.

Colella, P. and Woodward, P. R., 1984, The Piecewise Parabolic Method (PPM) for GasDynamical Simulations, J. Comput. Phys. 54: 174.

Couach, O., Kirchner, F., Jimenez, R., Balina, I. , Perego, S. and van den Bergh, H., 2004, A development of ozone abatement strategies for the Grenoble area using modelling and indicators, Atmos. Env. 38:1425-1436.

Derognat, C., 1998, Elaboration d'un Code Chimique Simplifié Applicable à l'Etude de la Pollution Photooxydante en Milieu Urbain et Rural, Diploma thesis report, Université Pierre et Marie Curie, France.

European Environmental Agency (EEA), 2003, EMEP/CORINAIR Emission Inventory Guidebook - 3rd edition, European Environmental Agency.

Gong, W. and Cho, H.-R., 1993, A numerical scheme for the integration of the gas phase chemical rate equations in a three-dimensional atmospheric model, Atmos. Env. 27A: 2147-2160. 


\section{Production of Ozone in Chamonix valley}

Grell, G.A, Dudhia, J. and Stauffer, J., 1994, A Description of the Fifth-Generation Penn State/NCAR Mesoscale Model (MM5). NCAR Tech Note TN-398, 122 pp.

Hong, S.-Y. and Pan, H.-L., 1996, Nonlocal boundary layer vertical diffusion in a medium-range forecast model, Mon. Wea. Rev. 124: 2322-2339.

Horowitz, L.W., Walters, S., Mauzerall, D.L., Emmons, L.K., Rasch, P.J., Granier, C., Tie, X., Lamarqe, J.-F., Schultz, M.G., and Brasseur, G.P., 2003, A global simulation of tropospheric ozone and related tracers: Description and evaluation of MOZART, version 2, J. Geophys. Res. 108 (D24): 4784.

Stockwell, R., Kirchner, F., Kuhn, M. and Seefeld, S., 1997, A new mechanism for atmospheric chemistry modelling, J. Geophys. Res. 102 (D22): 25847-25879.

Vautard, R., Martin, D., Beekmann, M., Drobinski, P., Friedrich, R., Jaubertie, A., Kley, D., Lattuati, M., Moral, P., Neininger, B. and Theloke, J., 2003, Paris emission inventory diagnostics from ESQUIF airborne measurements and chemistry transport model, J. Geophys. Res. 108 (D17): 8564. 